\title{
Grasslands Kahu timothy: quality pasture for animal performance
}

\author{
D.R. STEVENS, M.J. CASEY, J.D. TURNER, G.S. BAXTER and K.B. MILLER
} AgResearch, Gore Research Centre, Private Bag 50022, Gore

\begin{abstract}
Evaluations of Kahu timothy (Phleum pratense L.) included agronomy under mowing (1976-1979) and grazing (1980-1983), and animal performance from grazed pasture (1988-1993) and silage feeding (1989-1991). Agronomic testing showed that Kahu timothy was slow to establish, producing only $28 \%$ of the Grasslands Ruanui ryegrass (Lolium perenne L.) swards in the 6 months after sowing. Frequent, close defoliation severely reduced the yields of timothy and caused losses of plants, reducing longevity. A less frequent defoliation regime with a residual sward height of $30-50 \mathrm{~mm}$ gave the greatest sustainable yields. Under mowing Kahu produced significantly less than S51 timothy in summer and winter but under grazing Kahu was superior in spring and summer, resulting in significantly greater annual production. Animal performance testing showed hoggets grazing timothy in spring grew at $218 \mathrm{~g} /$ day, significantly greater than the $164 \mathrm{~g} /$ day achieved on Grasslands Nui ryegrass. The spring stocking rate on timothy was also significantly greater than on ryegrass, though utilisation of the forage was similar. When fed timothy/red clover silage lambs fed in winter grew at $98 \mathrm{~g} /$ day while lambs on standard ryegrass/ cocksfoot/white clover silage averaged a growth rate of only $44 \mathrm{~g} /$ day. From the assessment of the physiological state of individual tillers it was observed that timothy had a significantly higher proportion of its tillers with growing points present above ground through late spring and summer than ryegrass. This is suggested as a major reason for the depletion of timothy populations under close grazing. When grazed correctly in late spring and summer timothy can provide a perennial forage of high feeding value for livestock systems.
\end{abstract}

Keywords: animal performance, Grasslands Kahu, pasture quality, Phleum pratense

\section{Introduction}

Is timothy (Phleum pratense L.) the forgotten grass of the New Zealand pastoral system? Grasslands Kahu was bred from $\mathbf{S} 48$ Welsh material and a local ecotype (Langer 1990) and is often mentioned as a grass of high quality and palatability. However, its use has been restricted to that of a small addition to pasture mixtures because of a perceived inability to persist in intensively grazed pasture.

Timothy is a late-heading, leafy, many-tillered erect grass that has good spring and summer production under rotational grazing (Harris et al 1973). Although not very productive in late autumn and winter, timothy is moderately tolerant of winter treading (Brown \& Evans 1973) and heavy soils. These attributes mean timothy suits the cool moist environment typical of Southland.

Changing farming practices have increased the demand for high quality pasture feed for animal production and therefore farmers want more from grass cultivars than just dry matter production. The results of 4 experiments over 15 years compare pasture and animal production under a range of conditions. Kahu is compared with S51 timothy (UK) and Grasslands Ruanui or Grasslands Nui perennial ryegrasses (Lolium perenne $\mathrm{L}$ ).

\section{Methods}

Three of the trials outlined were done at the Gore Research Centre in Southland from 1976-1993. The silage experiments were on-farm trials at Balfour in northern Southland.

\section{Experiment 1}

A mowing evaluation of Kahu, S51 and Ruanui was sown in November 1976. Sowing rates were $5 \mathrm{~kg} / \mathrm{ha}$ for the timothy cultivars and $18 \mathrm{~kg} / \mathrm{ha}$ for the ryegrass as monocultures in $4 \times 1.2 \mathrm{~m}$ plots under both a frequent and infrequent cutting regime. Frequent plots were cut to $15 \mathrm{~mm}$ 2-weekly in spring, 3-weekly in autumn and 6-weekly in winter. Infrequent plots were cut to $30 \mathrm{~mm}$ 4-weekly in spring/summer, 6-weekly in autumn and 12-weekly in winter. The trial was a split plot design with cutting frequency as the main plot and cultivars as sub-plots with 3 replications. Pasture yield and purity was measured at each harvest and data analysed by season and year. Results presented are of the actual cultivar sown, rather than the total yield.

\section{Experiment 2}

Kahu, sown with Grasslands Huia white clover (Trifolium repens L.) was tested under sheep grazing from 1980-1983. Kahu was compared with S51 under 
frequent (4-week regrowth) and infrequent (6-week regrowth) grazing to a residue height of $15 \mathrm{~mm}$ in 4 replicates of $10 \times 15 \mathrm{~m}^{2}$ individually fenced plots. Pasture yield and botanical composition were measured at each grazing and data analysed by season and year.

\section{Experiment 3}

Kahu was included in an evaluation of 9 pasture mixtures grazed by goats for 3 years (1988-1991) and hoggets for 2 years (1991-1993). The results of the goat grazing trial are reported in Stevens et al. (1992) and include animal production from Kahu swards. Results of pasture and animal production from the sheep comparison of Kahu and Nui pastures both sown with Grasslands Tahora white clover in 2 replicates of individually fenced 0.20 ha plots are reported here. Management consisted of hogget grazing in spring (3-week regrowth) and autumn/early winter (6-week regrowth) utilising $80 \%$ of the pre-grazing herbage mass. During summer pastures were grazed using lambs to utilise $50 \%$ of the herbage on offer with dry ewes following to utilise a further $40 \%$ with a 6-week regrowth. Hogget growth was measured during the September to December period of 2 consecutive years. A put-and-take grazing system with 7 core animals was used. Pre- and post-grazing herbage mass was recorded at each grazing.

Detailed laboratory work assessed the reproductive status of timothy compared with perennial ryegrass over late spring and summer under goat grazing management. Two samples per replicate x 2 replicates were collected monthly from October to March over 2 consecutive years. Tillers were sampled randomly in the field and cut at ground level. Fifty random tillers were selected from each sample and scored as vegetative (no nodes present), elongated (nodes present) or seedhead (seedhead emerging).

\section{Experiment 4}

Silage made from different pasture mixtures was assessed in an on-farm trial on the property of M.B. Dillon, Nine Mile Road, Balfour. The two pasture mixtures, Kahu timothy with Grasslands Pawera red clover (Trifolium pratense L.) and Grasslands Puna chicory (Cichorium intybus L.) with Grasslands Manawa hybridryegrass (Loliumperenne L. x Lolium multijlorum L.) and Huia white clover were sown in February 1988. Silage was made from the individual pastures in the spring/autumn of 3 consecutive years (1989-1991). The pastures were then grazed throughout the rest of the year, In each year this silage was fed indoors to 40 cryptorchid Romney lambs that had been preconditioned to the silage diet for 2 weeks. Their liveweight gains were compared with those from summer-made pasture silage from an older pasture consisting of ryegrass, cocksfoot (Dactylis glomerata L.), white clover and other grasses over periods of 70, 69 and 57 days in the winters of 1989, 1990 and 1991 respectively. Silage intake and herbage feed analysis were both measured in each year. Silage was fed daily at a level which ensured the opportunity for a 20\% rejection of forage on offer. The methods used in these trials are more fully described in Stevens et al. (1989).

\section{Results}

\section{Experiment 1}

Kahu was significantly slower to establish than both S51 and Ruanui ryegrass (Table 1). In the following 2 years Kahu yields improved but were still significantly lower than S51 in summer and winter. Ruanui yielded more than Kahu in summer, autumn and winter. The comparison of the two cutting regimes (Table 2) showed that Ruanui was not as sensitive to severe defoliation as Kahu, as timothy yield was significantly lower under hard, frequent cutting than under infrequent cutting. Kahu and S51 had similar plant populations remaining after 3 years of the trial (Table 3) and they were similarly lower under frequent cutting.

Table 1 Yields (kg DM/ha) under infrequent lax cutting during establishment year and the following hvo years. (mean yields)

\begin{tabular}{lcccc}
\hline & Kahu & Ruanui & S51 & Isd \\
\hline Establishment & $\mathbf{1 6 3 0}$ & 5830 & 3060 & 250 \\
Summer & 5550 & $\mathbf{6 0 9 0}$ & 6300 & $370^{\prime}$ \\
Autumn & $\mathbf{2 4 8 0}$ & $\mathbf{3 3 3 0}$ & 2630 & $\mathbf{2 5 0 *}$ \\
Winter & 540 & $\mathbf{8 8 0}$ & $\mathbf{7 0 0}$ & $110^{\prime}$ \\
Spring & 6470 & $\mathbf{6 2 0 0}$ & 6530 & $\mathbf{5 7 0 n s}$ \\
\hline
\end{tabular}

Table 2 Comparison of yields (kg DM/ha) frequent (hard) and Infrequent (lax) cutting

\begin{tabular}{lrrr}
\hline & Kahu & Ruanui & Isd \\
\hline Frequent & 5400 & 15100 & \\
Infrequent & 15040 & 16500 & 1200 \\
\hline
\end{tabular}

Table 3 Comparison of the $\%$ live plant numbers, using point analysis, of Kahu and $\mathbf{S} 5 \mathbf{1}$ after three years

\begin{tabular}{lccc}
\hline & Kahu & S51 & Isd \\
\hline Frequent & 35 & 25 & \\
Infrequent & 75 & 85 & 38.5 \\
\hline
\end{tabular}


Table 4 Seasonal and annual timothy production (kg DM/ha) under frequent and infrequent grazing (mean of two full production years)

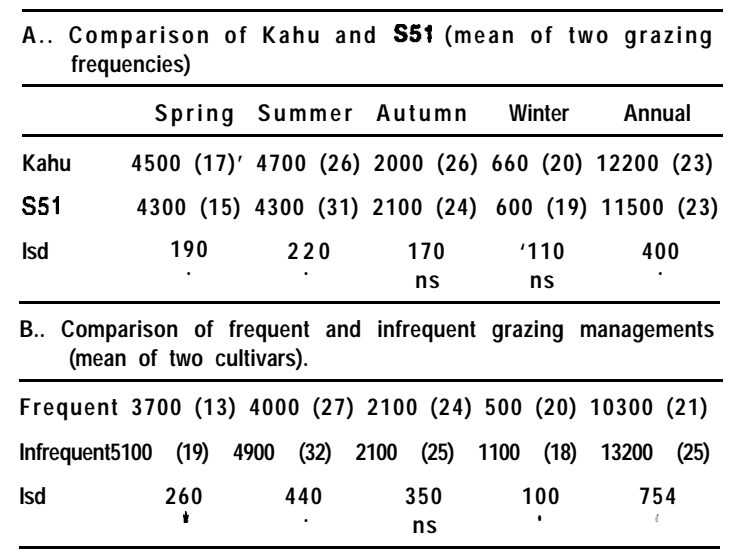

1 Figures in brackets are mean $\%$ clover content.

\section{Experiment 2}

When assessed in a grazed pasture Kahu produced significantly more herbage than S51 in spring and summer, resulting in a significantly higher annual yield (Table 4A). The clover content of both timothy swards was similar, making up $23 \%$ of the annual herbage production.

Grazing frequency produced the greatest difference in winter, moderate in spring and summer and no significant difference in autumn (Table 4B). Frequent grazing of timothy reduced dry matter production by $55 \%$ of infrequent grazing in winter, $29 \%$ in spring and $18 \%$ in summer. The clover content in spring and summer was also reduced by frequent grazing.

\section{Experiment 3}

Hoggets grazing Kahu had a significantly higher liveweight gain $(218 \mathrm{~g} /$ day $)$ than those on Nui (164 g/ day) during spring (Table 5). The spring stocking rate of Kahu was significantly higher (37.4 hoggets/ha) than of Nui (33.8). Although Kahu had a significantly higher pre-grazing herbage mass, it also had a higher postgrazing herbage mass, resulting in a similar level of pasture utilisation for Kahu (69\%) and Nui (71\%). The composition of the two pastures over the two years did not differ significantly in any of the measured features during spring (Table 6).

Laboratory inspection of tillers from 30 October to 19 March showed very clearly that timothy had a different pattern of tiller development through the seeding phase (Figure la,b,c). Recovery of vegetative tiller numbers lagged behind that of ryegrass by up to 2 months (Figure la). The percentage of tillers that
Table 5 Hogget liveweight gains in spring (mean of two years)

\begin{tabular}{lccccc}
\hline & $\begin{array}{c}\text { Lwt gain } \\
\text { (g/day) }\end{array}$ & $\begin{array}{c}\text { Stocking } \\
\text { Rate } \\
\text { (hoggest/ha) }\end{array}$ & $\begin{array}{c}\text { Pm-grazing } \\
\text { herbage } \text { a s } \\
\text { (kgDM/ha) }\end{array}$ & $\begin{array}{c}\text { Post-grazing } \\
\text { herbage } \\
\text { mass } \\
\text { (kgDM/ha) }\end{array}$ & $\begin{array}{c}\text { Utilisation } \\
\%\end{array}$ \\
\hline Kahu & 216 & 37.4 & 2640 & 660 & 69 \\
Nui & 164 & 33.6 & 2140 & 620 & 71 \\
Isd & 27 & 3.2 & 400 & 160 & 10 \\
& & & 4 & & ns \\
\hline
\end{tabular}

Table6 Percentage composition of Kahu timothy and Nui ryegrass swards in spring.

\begin{tabular}{|c|c|c|c|c|c|}
\hline & $\begin{array}{l}\text { Sown } \\
\text { Leaf }\end{array}$ & $\begin{array}{l}\text { Grass } \\
\text { Stem }\end{array}$ & Legume & $\begin{array}{l}\text { Other } \\
\text { Species }\end{array}$ & Dead \\
\hline Kahu & 59 & 12 & 8 & 19 & 2 \\
\hline Nui & 52 & 15 & 10 & 22 & 1 \\
\hline \multirow[t]{2}{*}{ Isd } & 26 & 6 & 6 & 27 & 5 \\
\hline & $\mathrm{ns}$ & $\mathrm{ns}$ & $\mathrm{ns}$ & $\mathrm{ns}$ & ns \\
\hline
\end{tabular}

remained elongated with nodes above ground level was much higher in timothy than ryegrass (Figure lb). The transition from elongated back to vegetative took much longer in timothy than ryegrass. Ryegrass seedheads emerged quickly after elongation and in great number (Figure lc) and then seedhead production ceased. Timothy seedhead production (Figure lc) was much later and was insignificant, even though large numbers of elongated tillers had been present (Figure lb).

\section{Experiment 4}

Silage from a Kahu timothy $(50-60 \%$ by dry weight)/ Pawera red clover pasture gave lamb growth rates of 74-128 g/day over 60- to 70-day periods (Table 7). The range of lamb growth from standard perennial ryegrass, cocksfoot, white clover silage ranged from 7 to $76 \mathrm{~g} /$ day over the same periods. The mean lamb growth rate from timothy/red clover silage was $98 \mathrm{~g} /$ day, whereas that on standard pasture silage averaged $44 \mathrm{~g} /$ day. Lambs fed chicory-based silage (3040\% chicory by dry weight) grew at higher rates, averaging 142 glday.

Table 7 Lamb liveweight gain ( $\mathrm{g} / \mathrm{head} / \mathrm{day})$ and intake ( $\mathrm{kg} / \mathrm{head}$ day) on different silage diets.

\begin{tabular}{|c|c|c|c|c|c|c|}
\hline & Lwtgain & $\begin{array}{c}1969 \\
\text { Intake }\end{array}$ & Lwtgain & $\begin{array}{c}1990 \\
\text { Intake }\end{array}$ & Lwtgain & $\begin{array}{c}1991 \\
\text { Intake }\end{array}$ \\
\hline Kahu/Red 7 & 4 & 1.26 & 93 & 1.33 & 126 & 1.48 \\
\hline Pasture & 46 & 1.41 & 7 & 1.00 & 76 & 1.26 \\
\hline Chicory & Mix & . & 125 & 1.60 & 156 & 1.51 \\
\hline
\end{tabular}


Figure 1 Changes in the physiological state of timothy and ryegrass tillers in late spring and summer
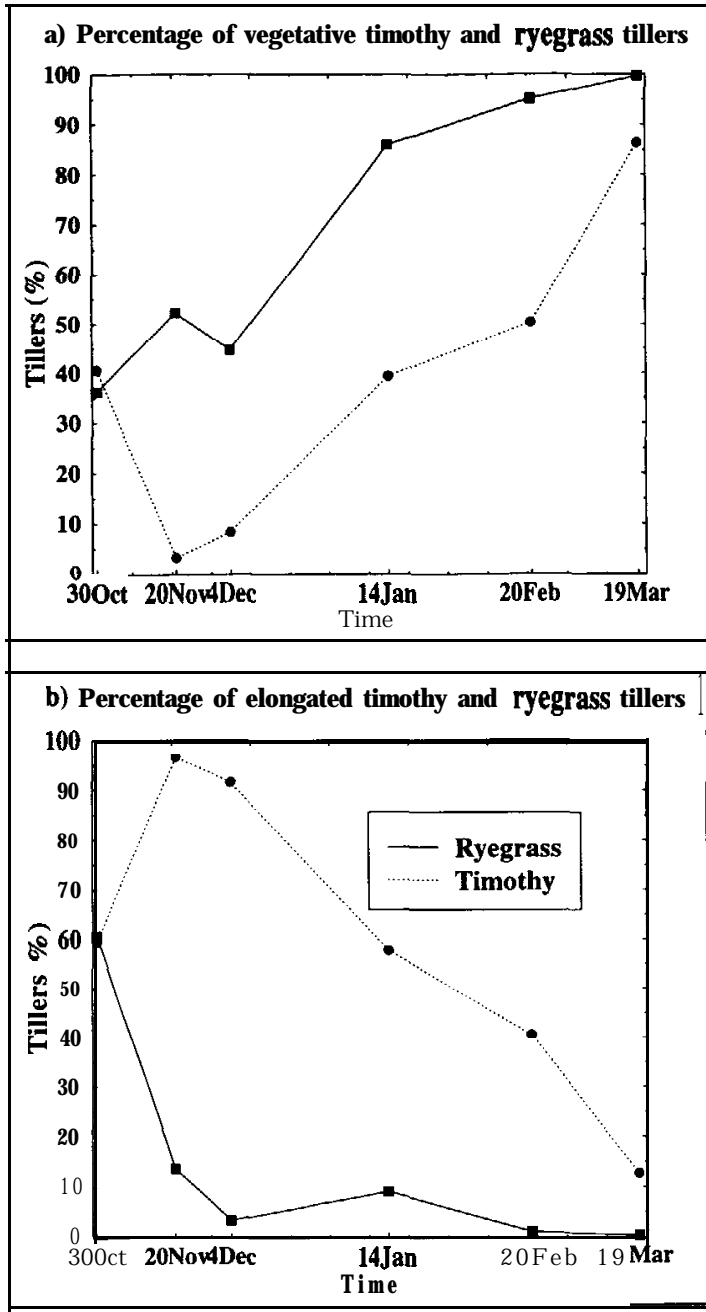

c) Percentage of seeded timothy and ryegrass tillers

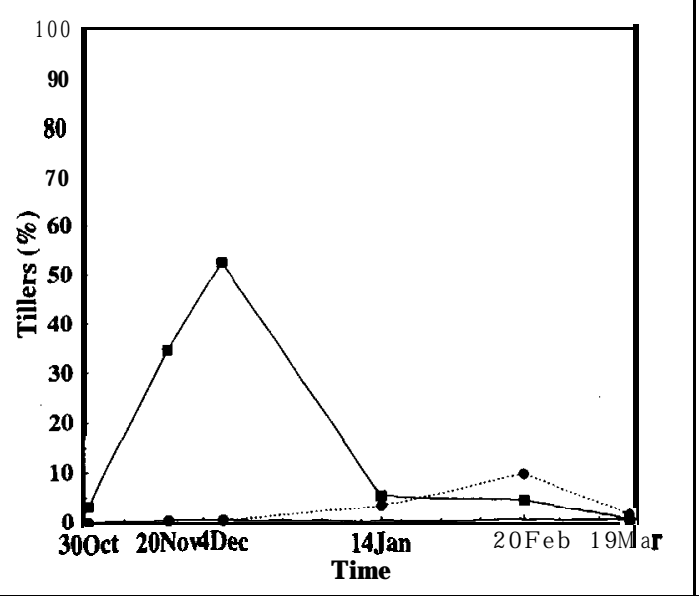

Lamb silage intakes (Table 7) were lowest on standard pasture except in 1989, intermediate on timothy/red clover and highest on chicory-based silage. Digestibility (Table 8) was lowest on standard pasture, highest on chicory silage and intermediate on timothy silage. Generally timothy/red clover silage had the highest $\mathbf{p H}$, protein and ammonium- $\mathrm{N}$ levels (Table 8).

Table 8 Feed value estimates of silages made in 1989,1990 and 1991.

\begin{tabular}{|c|c|c|c|c|c|}
\hline \multirow[b]{2}{*}{1969} & \multirow[b]{2}{*}{$\begin{array}{l}\text { Timothy } \\
\text { Standard } \\
\text { Chicory }\end{array}$} & \multicolumn{2}{|c|}{ pH Protein } & \multicolumn{2}{|c|}{$\begin{array}{l}\% \mathrm{NH}_{4}-\mathrm{N} \% \text { Drymatter } \\
\text { Digestibility (\%) }\end{array}$} \\
\hline & & $e^{n / a} n / a$ & $\begin{array}{r}14.9 \\
16.3\end{array}$ & $\begin{array}{l}n / a \\
n / a\end{array}$ & $\begin{array}{c}60.6 \\
61.4 \\
.\end{array}$ \\
\hline 1990 & $\begin{array}{l}\text { Timothy } \\
\text { Standard Pasture } \\
\text { Chicory Mix }\end{array}$ & $\begin{array}{r}4.04 \\
3.97 \\
3.96\end{array}$ & $\begin{array}{c}19.1 \\
14.1 \\
12.6\end{array}$ & $\begin{array}{l}0.373 \\
0.191 \\
0.120\end{array}$ & $\begin{array}{l}69.2 \\
64.0 \\
73.7\end{array}$ \\
\hline 1991 & $\begin{array}{l}\text { Timothy } \\
\text { Standard Pasture } \\
\text { Chicory Mix }\end{array}$ & $\begin{array}{r}4.53 \\
4.01 \\
3.65\end{array}$ & $\begin{array}{r}16.9 \\
11.9 \\
17.1\end{array}$ & $\begin{array}{l}0.316 \\
0.170 \\
0.164\end{array}$ & $\begin{array}{l}66.5 \\
61.1 \\
72.9\end{array}$ \\
\hline
\end{tabular}

\section{Discussion}

Kahu timothy has long been used as a minor component of pasture mixtures sown on heavier soil types for some unspecified animal benefits. Preconceptions about the longevity and production of timothy have restricted its use. The data collated here along with other experimental work suggest a more major role for timothy is possible.

Establishment is critical in determining good performance from timothy pastures. Timothy is very slow to establish (Table 1) so grazing over the first six months must be carefully planned. Grazing for weed control must be balanced with the need to ensure continued plant development. When sown in complex mixtures timothy does not compete well during establishment and therefore subsequently does not contribute in proportion to the seed sown.

Once established, grazing management determines the persistence of timothy. Short regrowth periods and close defoliations depleted timothy plant numbers (Table 3 ) and also reduced pasture yields (Tables 2,4B). Less intensive defoliations with a residual pasture height of $30-50 \mathrm{~mm}$ gave the greatest sustainable yield for both the work reported here and that of Harris et al. (1973).

Research has shown that timothy yields can be similar to that of other pasture cultivars (Harris et al. 1983; Watkin 1975; Lewis \& Cullen 1973). Although 
timothy produced less than ryegrass in several seasons in the trials reported here, it still produced more than the animal requirement for most farming situations. Timothy also has a reputation for being suitable only for wetter climates, but data collected by Watkin (1975) in Canterbury shows that timothy produced as well as ryegrass on a deep though drought-prone soil.

Late-spring and early-summer management are critical in maintaining the longevity of timothy pastures. The data (Figures 1-3) show that the growing points of timothy are more vulnerable to damage by grazing than ryegrass due to elongation above ground level for a much longer and later period. Although timothy has generally similar morphological features to ryegrass for much of the year, this period of prolonged elongation of the growing points is a key difference and one that significantly affects plant longevity. This particular trait also ensures that topping to control seedhead production of Kahu is rarely required in grazed pastures.

Improved animal performance from timothy was demonstrated for both grazed and conserved pasture. The increased animal performance (Table 5) was due to the timothy because the clover content was the same for both pasture types in the grazing evaluation (Table 6). Lewis \& Cullen (1973) achieved similar results when comparing ryegrass with timothy/cocksfoot pastures. British work by Davies \& Morgan (1982a) also found that timothy gave higher lamb liveweight gains than other grasses when grazing pure swards with ewes and lambs. However, the animal growth advantages from timothy have not been well related to empirical measurements such as digestibility, crude protein or acid detergent fibre (Davies \& Morgan 1982b; Rode \& Pringle 1986; Stevens et al. 1992).

Timothy/red clover silage produced good lamb liveweight gains in winter when weight gains for any animal class are difficult to achieve. Liveweight gain in this instance was generally well related to intake and feed values. The higher $\mathrm{pH}$ of timothy/ red clover silage (Table 8) was due to the high legume content which also increased ammonium nitrogen levels. Improvements in the proportion of timothy in the sward from 55\% to $75 \%$ may increase animal liveweight gain by reducing the ammonium nitrogen levels.

The longevity of timothy in pastures can be more assured with particular attention to establishment and the appropriate grazing management, especially in summer. For instance, the pastures from which the silage was made are now 6 six years old and sited in an area prone to dry soils in summer. Those used in the animal performance trial on summer-moist soils show no sign of deterioration after 5 years. Gorman (1950) also reported 23-year-old stands of timothy in Southland where annual seed crops were followed by hard grazing in autumn and winter.

Advantages from the greater animal performance from timothy-based pastures make timothy an option that is worthy of reconsideration by New Zealand farmers. Even between timothy genotypes animal intake varies (Mason \& Flipot 1988), so future improvements in this species can be expected.

\section{ACKNOW LEDGEMENTS}

The authors would like to thank M. and G. Dillon for all their effort in the silage feeding trials, D. Allan for technical assistance, and field staff at the Gore Research Centre.

\section{REFERENCES}

Brown, K.R.; Evans, P.S. 1973. Animal treading. A review of the work of the late D.B. Edmond. New Zealand journal of agricultural research 1:21722.

Davies, D.A.; Morgan, T.E.H. 1982a. Performance of ewes and lambs on perennial ryegrass, cocksfoot, tall fescue and timothy pastures under upland conditions. Journal of agricultural science, Cambridge 99: 145-151.

Davies, D.A.; Morgan, T.E.H. 1982b. Herbage characteristics of perennial ryegrass, cocksfoot, tall fescue and timothy pastures and their relationship with animal performance under upland conditions. Journal of agricultural science, Cambridge 99: 153161.

Gorman, L.W. 1950. Strains of timothy. New Zealand journal of science and technology 32A: $1-15$.

Harris, A.J.; Brown, K.R.; Turner. J.D.; Johnston, J.M.; Ryan, D.L.; Hickey, M.J. 1973. Some factors affecting pasture growth in Southland. New Zealand journal of agriculturul research I: 139-63.

Langer, R.H.M. 1990. Pasture plants. Chapter 2 In Pastures: their ecology and management. Langer, R.H.M. ed. Aüuckland; Oxford University Press.

Lewis, K.H.C; Cullen, N.A. 1973. Lamb, growth on "Long" and "short" grazed pastures of ryegrass or timothy/cocksfoot. Proceedings of the New Zealand Grassland Association 34 (2): 199-204.

Mason, W.N.; Flipot, P.M. 1988. Evaluation of timothy cultivars for voluntary intake and nutrient components. Canadian journal of animal science 68: 1121-1 129.

Rode, L.M.; Pringle, W.L. 1986. Growth, digestibility and voluntary intake by yearling steers grazing timothy (Phleum pratense) or meadow foxtail 
(Alopecurus pratense) pastures. Canadian journal of animal science 66: 463-472.

Stevens, D.R.; Lee, D.M.; Dillon, M.B.; Turner J.D. 1989. A co-operative programme to extend lamb production in Southland. Proceedings of the New Zealand Grassland Association 50: 73-78.

Stevens, D.R.; Baxter, G.S.; Casey, M.J.; Miller, K.B.; Lucas, R.J. 1992. Comparison of six grasses for animal production. Proceedings of the New Zealand Grassland Association 54: 147-150.

Watkin, B.R. 1975. The performance of pasture species in Canterbury. Proceedings of the New Zealand Grassland Association 36: 180-190. 